\title{
Bucking the Trend: Female Labor Market Participation in Kosovo
}

\section{Ardiana Gashi}

Faculty of Economics, University of Prishtina, Kosovo

Ardiana.Gashi@uni-pr.edu

\section{Artane Rizvanolli}

Department of Economics, Riinvest College, Kosovo artane.rizvanolli@riinvest.net

\section{Nick Adnett}

Business School, Staffordshire University, UK

N.J.Adnett@staffs.ac.uk

\section{CroEconSur}

Vol. 21

No. 2

December 2019

pp. 85-116

Received: August 13, 2018

Accepted: September 9, 2019

Research Article

doi:10.15179/ces.21.2.3

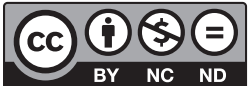

\section{Abstract}

This paper adds to the limited research conducted on labor markets with low female labor force participation, providing the first multivariate analysis for Kosovo. The determinants of female labor force participation (FLFP) in Kosovo are investigated utilizing an eclectic model, comprising of individual, household, and socio-economic determinants, to analyze data from the Kosovo Labor Force Survey. Both supply and demand factors contribute to the explanation of the low FLFP in Kosovo. The results confirm that: age, marital status, education, labor market demand and the composition of the household are significant determinants of FLFP. These findings indicate the importance of taking a 
household level approach when analyzing labor force participation in countries with low female force participation.

Keywords: female labor force participation, gender, household, inactivity

JEL classification: J08, J16, J21

\section{Introduction}

In recent decades labor markets in almost all parts of the world have experienced falling gender gaps (Stotsky, Shibuya, Kolovich, \& Kebhaj, 2016). As gender gaps in educational achievement have been reduced or reversed and fertility rates have fallen, female participation and employment rates have risen, closing the traditional gender gaps in these latter two measures (Goldin, 2014; Olivetti \& Petrongolo, 2016). When set against these almost universal trends in Europe (Christiansen, Lin, Pereira, Topalova, \& Turk, 2016), the behavior of gender gaps in Kosovo's labor market provides a puzzle. The latest Labor Force Survey in Kosovo estimates the female labor force participation (FLFP) rate to be 20 percent (KAS, 2018), the lowest in Europe and Central Asia. According to the latest data, the female employment to working age population rate is around 12.7 percent and the female unemployment rate is 36.6 percent (KAS, 2018). These rates differ by a factor of four from those typical in the EU-28 and even in the context of the Western Balkans make Kosovo a clear outlier. At the same time these Labor Force Surveys find no evidence of a significant unconditional gender wage gap in Kosovo, confirming the findings of an earlier study (Pastore, Sattar, \& Tiongson, 2013). To add to this puzzle, successive labor market surveys provide no evidence that the labor market outcomes for females in Kosovo have been improving in recent years.

This paper investigates this puzzle, concentrating upon the causes of low female participation rates in Kosovo. The main reason for this focus is that low female 
participation rates are likely to be associated with a substantial loss of social welfare. Substituting market work for home production enables income to grow faster than productivity (Kabeer, 2012) and potentially generates a virtuous circle of faster growth and rising female labor force participation rates (Duflo, 2012; Bandiera \& Natraj, 2013). Faster growth follows from society better exploiting the actual and potential skills of their female populations and substituting market for home production (IMF, 2013). Since increases in the female employment rate are associated with a rising proportion of low productivity and low-income females being employed, poverty rates also tend to fall. In addition, for mothers there is some evidence that being in full-time employment raises happiness and life satisfaction compared to being in part-time employment or home-production (Berger, 2013). Overall, higher female labor force participation is likely to be associated with equity gains as households and society as a whole share the costs of renewing the country's population more evenly. Finally, for labor-exporting countries like Kosovo, the failure to provide economic, social, and political empowerment for more educated females is likely to encourage a female brain drain (Nejad \& Young, 2014). Curberes and Teignier (2015) have tried to quantify some of these costs, focusing on those associated with the participation gender gap and the distortions in the choice of occupations. They estimate that with a 28 percent income loss per capita, Kosovo has the highest loss in their sample of seven Balkan countries and Turkey.

This paper is organized as follows. In the following section a more detailed analysis is provided of what is known about women's participation in the labor market in Kosovo and the extent to which demographic factors can explain the low FLFP. Following a review of previous relevant empirical analyses, a theoretical framework for this investigation and an empirical model specified to test the determinants of FLFP in Kosovo are developed in section three. The characteristics of the data are then briefly reviewed. Section four presents the results of the probit analysis of the determinants of female participation and explores the causes of the gender gap in participation. The final section discusses some policy implications of the findings. 


\section{Low Female Participation: A Literature Review}

According to the Labor Force Survey data, Kosovo had the lowest female participation rate in 2017 and, at 45 percentage points, the largest participation gender gap in Europe and Central Asia (World Bank, 2018). This gap is much larger than in other neighboring successor states of former Yugoslavia. Although the fertility rate has fallen by two-thirds over the last forty years, with over half of its population aged 25 or under, Kosovo has a very young population compared to the EU-28 and most other Western Balkan countries. The working age population is taken as people aged 15 to 64 , though many of the younger members will be in full-time education and therefore classified as inactive. The size of the latter group may also be increased by the very high youth unemployment rates in Kosovo. Countries with a younger population will tend, ceteris paribus, to have lower participation rates and lower employment rates. In addition, countries with a younger population tend to have a higher proportion of their female population who are inactive due to maternity or caring for young children. Hence, Kosovo's low female participation and employment rates and the large gender gaps in these two rates can partly be explained by the age structure of its population. As can be seen in Table 1, the labor force participation gender gap initially increases by age, peaking at the age 40-44. As can be observed, the gender gap in labor force participation in Kosovo is significantly higher than in the EU-28, but also than in the neighboring countries (Montenegro, North Macedonia and Serbia).

A further factor contributing to the low female participation rate in Kosovo is the high rate of unemployment. According to the 2017 Labor Force Survey, the unemployment gender gap was 8 percent for those of working age. The higher female unemployment rate is surprising given the size of female inactivity and the greater probability of unemployed females moving into inactivity. A World Bank report (2014) utilized the panel element in the LFS from 2012 to examine labor market dynamics in Kosovo and found that while there was high persistence in employment and inactivity, this was lower amongst the unemployed. For males who were unemployed in the first quarter, 16.9 percent were employed by the 
fourth quarter of 2012 and only 10.4 percent became inactive. However, for females only 3.4 percent of the unemployed were in employment in the fourth quarter and 26.2 percent of them had stopped actively seeking work. This suggests that the very low female participation rates in Kosovo can partly be explained by the high incidence of discouraged female workers.

Table 1: Gender Gaps in Labor Force Participation, by Age Group

\begin{tabular}{|c|c|c|c|c|c|c|c|c|c|c|c|c|c|c|c|}
\hline \multirow{2}{*}{$\begin{array}{c}\text { Age } \\
\text { group }\end{array}$} & \multicolumn{3}{|c|}{ Kosovo } & \multicolumn{3}{|c|}{ EU-28 } & \multicolumn{3}{|c|}{ Montenegro } & \multicolumn{3}{|c|}{ North Macedonia } & \multicolumn{3}{|c|}{ Serbia } \\
\hline & M & F & Gap & M & F & Gap & M & $\mathbf{F}$ & Gap & M & F & Gap & M & $\mathbf{F}$ & Gap \\
\hline $15-19$ & 11 & 5 & 7 & 22 & 19 & 2 & 15 & 9 & 6 & 16 & 7 & 9 & 13 & 8 & 5 \\
\hline $20-24$ & 54 & 25 & 29 & 65 & 58 & 8 & 54 & 47 & 7 & 64 & 38 & 27 & 57 & 38 & 20 \\
\hline $25-29$ & 81 & 32 & 49 & 88 & 77 & 11 & 81 & 78 & 3 & 89 & 66 & 23 & 83 & 70 & 12 \\
\hline $30-34$ & 89 & 28 & 61 & 93 & 79 & 14 & 88 & 78 & 10 & 94 & 69 & 24 & 91 & 79 & 12 \\
\hline $35-39$ & 85 & 23 & 63 & 94 & 81 & 13 & 91 & 70 & 21 & 94 & 70 & 24 & 92 & 81 & 10 \\
\hline $40-44$ & 87 & 23 & 64 & 93 & 82 & 11 & 92 & 75 & 17 & 94 & 68 & 27 & 90 & 82 & 8 \\
\hline $45-49$ & 85 & 22 & 63 & 92 & 82 & 10 & 88 & 66 & 23 & 93 & 62 & 31 & 89 & 78 & 11 \\
\hline $50-54$ & 77 & 17 & 60 & 89 & 78 & 11 & 82 & 61 & 21 & 90 & 55 & 35 & 84 & 70 & 14 \\
\hline $55-59$ & 66 & 14 & 52 & 81 & 68 & 13 & 68 & 49 & 19 & 81 & 45 & 36 & 74 & 54 & 20 \\
\hline $60-64$ & 50 & 12 & 38 & 53 & 38 & 15 & 45 & 25 & 19 & 52 & 20 & 32 & 51 & 25 & 25 \\
\hline 15-64 & 65 & 20 & 45 & 79 & 68 & 11 & 71 & 57 & 14 & 78 & 52 & 27 & 74 & 60 & 14 \\
\hline
\end{tabular}

Sources: For Kosovo: Labor Force Survey 2017; for other countries: Eurostat (2019).

There has been some limited research into the causes of these relatively large participation gender gaps in Kosovo and most of this has relied upon bivariate analysis (KAS, 2018). Half of inactive women cite "personal or family responsibilities" or "looking after children or incapacitated adults" as the main reason for not looking for a job (KAS, 2014). Only 4 percent of inactive males cited either of these two reasons. However, for females the probability of citing either of these two reasons was strongly linked to educational attainment: only 27 percent of females with tertiary education gave these two as the main reasons for their inactivity. Overall, women who had completed secondary education were nearly five times more likely to participate in the labor market compared to those with just primary education. The lower participation of less educated women cannot be attributed to a higher probability of this group being students. On the 
contrary, just 15.6 percent of inactive women who had only completed primary education reported being inactive due to participation in education or training, compared to 23 percent and 34 percent of their counterparts who have completed vocational and general secondary education, respectively.

While having young children is strongly associated with low female participation rates, female employment rates are largely unaffected by the age of the youngest child. In a study unrelated to the current analysis, researchers from the World Bank (2014) analyzed the data from the 2012 LFS concluding that having young children in Kosovo did not appear to push females out of employment, but it did tend to prevent inactive mothers from trying to find employment (World Bank, 2014). Bi-variate analysis also indicates that divorced and single women had higher participation rates than those who were married or widowed, that women living in urban areas were twice as likely to be economically active compared with those in rural areas, and that ethnic differences were relatively small.

Cross-country differences in FLFP participation have been attributed to differences in: social norms and gender identities and preferences (Akerlof \& Kranton, 2000; Fernández, Fogli, \& Olivetti, 2004; Bertrand, 2011; Camussi, 2013; Fernández, 2013), religion (Spierings, Smits, \& Verloo, 2009; Bayanpourtehrani \& Sylwester, 2013; Gouda \& Potrafke, 2016), the nature and extent of family-friendly policies including public provision of childcare (Blau \& Kahn, 2013; Cipollone, Pattacchini, \& Vallanti, 2014; Pronzato \& Sorrenti, 2015; Christiansen et al., 2016), the taxation of secondary earners (Bick \& FuchsSchündeln, 2012) and in the evolution of industrial structure and the degree of marketization of home production (Goldin, 2006; Olivetti \& Petrongolo, 2016). There has been some limited research on labor markets with unusually low female participation and these have largely focused on the first and last of these explanations. Verne, Barry, and Guennouni (2014), analyzing the causes of low female labor market participation in Arab countries, particularly Morocco, emphasize the role of economic growth and gender norms in these countries. They find that economic growth has created only a relatively small number of new jobs 
and that few of these have been in female-friendly sectors. Hence, women have faced a generally weak demand for labor, particularly those women in urban areas with secondary education. In addition, employers' and households' preferences have favored male over female workers. Assaad, Hendy, Lassassi, and Yassin (2018) also investigate this "MENA paradox", adding a contraction in public sector employment opportunities for women with higher education as a further explanatory factor. Klasen and Pieters (2015) provide a similar explanation for the low and stagnant female labor force participation in urban India, despite falling fertility rates, economic growth and rising educational attainments. They find that changes in the sectoral structure of employment have favored male-dominated sectors, while on the supply-side rising male earnings appear to have reduced a household's supply of female labor. In addition, the supply of female workers has been constrained by declining positive selection of females into higher education and the stigma attached to educated women working in low-skilled employment, the latter being held responsible for the u-shaped relationship between a woman's educational attainment and labor market participation.

Given historical and cultural similarities with Kosovo, Turkey provides an interesting comparison. Turkish female participation rates were falling in the three decades after 1980 and by 2013 Turkey had the largest gender participation gap in Europe and Central Asia. Uraz et al. (2010) find that participation is particularly low amongst less-educated women in urban areas. They attribute this to the low wage rates and high child-care costs facing such women. Moreover, while stronger traditional family values appear to favor female participation in rural areas, they have the reverse effect in urban areas. Karaoglan and Okten (2012) find that having more adults in the household increases Turkish wives' participation, while their participation responds positively to their husband's job loss and under-employment (the added worker effect) and negatively to a rise in the unemployment rate (the discouraged worker effect). Looking at all transition economies following the 2008 financial crisis, Khitarishvili (2013) found that 
the positive added-worker effect on female participation rates outweighed the negative discouraged worker effect.

Ethnic and cultural similarities make the behavior and determinants of FLFP in Albania also of special interest. During transition to a market economy, FLFP declined in Albania with women finding it particularly difficult to reenter employment after unemployment or childbearing periods. García-Pereiro and Dileo (2017) find that the probability of a women being in employment increases with levels of completed education and household income in Albania. In addition, cultural proxies play an important role. Having a working mother and a father who has completed secondary or tertiary education significantly increase the probability of a woman being in employment. Shehaj et al. (2016) find that certain measures of social capital have a positive effect on FLFP in Albania (number of organizations/groups that women participated in), but not in Macedonia (time spent in contact with non-family members).

Some of the causes identified in the literature above, such as insufficient economic growth and overall job creation, as well as social norms and stereotypical gender roles at the household level, appear to be applicable to Kosovo. However, the sectoral composition of labor demand does not seem to be a key factor in explaining the gender gap in the Kosovan labor market. An examination of the structure of employees by gender in the major economic sectors suggests no major structural changes in recent years, though women are under-represented in some of the key industries in the private sector (construction, manufacturing, accommodation, and food services) and have above-average representation in public-dominated sectors (education and healthcare provision). The discussions on discouraged and added worker effects are particularly interesting in the context of Kosovo. As explained in the previous section, discouraged unemployment is likely to be widespread among women in Kosovo. However, the added-worker effect is also likely to be particularly strong, given household characteristics, labor market conditions, and policy context. Namely, while men are typically considered as the main bread-winners, women are responsible for care-taking in 
the household. In this context, a decision regarding women seeking employment is likely to incorporate the labor market outcome/decision of her husband (and other males in the household), as in the so-called "classical" type of household, as discussed by Eckstein and Lifshitz (2015). Given the high unemployment faced by men and the absence of unemployment benefits in Kosovo, the increased "pressure" on women in households with unemployed men may be a particularly strong factor in determining FLFP.

In the following section we build on the discussion above to specify a model which can be used to examine the determinants of FLFP using LFS data for Kosovo.

\section{The Causes of Low Female Participation Rates in Kosovo: Data and Model Specification}

For this empirical investigation, data are extracted from the 2013 Kosovo Labor Force Survey (LFS). The LFS is implemented every year by the Kosovo Agency of Statistics, with the methodology following the Eurostat guidelines. The LFS is designed as a continuous household survey, with data collection throughout each week of the year. For this survey, the stratified two-stage sample design is used. The sampling frame is based on the data and cartography from the 2011 Kosovo Census. For the 2013 LFS, a sample of 600 Enumeration Areas (EA) was selected with probability proportional to size, within each stratum, where the measure of size was based on the number of households in the EA from the 2011 Kosovo Census frame. A sample of eight households was selected for the LFS in each sample EA, for a total original sample size of 4,800 households each quarter. In order for the sample estimates from the 2013 Kosovo LFS to be representative of the population, sampling weights were applied, with a household weight attached to each sample household record in the data files. Assuming that there is a latent variable representing the utility of a woman (and her household), due to participation in labor market $(Y)$, which is explained by explanatory variables 
$\left(X_{i}\right)$, and that a woman participates in the labor market only if a threshold level of $Y$ is reached, the following probit model is estimated to investigate the probability (Pr) of labor force participation (Equation 1):

$$
\operatorname{Pr}\left(Y=1 \mid X_{i}\right)=\Phi\left(\beta_{i} X_{i}\right)
$$

where the dependent variable $Y$ is equal to one if the woman participates in the labor force, i.e. is either working or not working but actively seeking a job, and 0 otherwise; $\Phi$ is the cumulative distribution function of the standard normal distribution and $\beta_{i}$ are the parameters of the explanatory variables $X_{i}$ that will be estimated by maximum likelihood.

Given the characteristics of the Kosovan society and informed by the previous research reviewed above, an eclectic theoretical framework was adopted in choosing the explanatory variables to be included in the model. The adoption of models which work well when studying labor market behavior in advanced economies may lead to incorrect or inappropriate conclusions being drawn unless adjustments are made to reflect the situation in Kosovo. Thus, starting from the neo-classical theory of labor supply, initially a range of individual and market demand variables which affect the relative price of market work, non-market work and leisure faced by women and their tastes and preferences for these activities are included. In addition, the prevalence of traditional patriarchal households and patrilocal marriage practices, especially in rural Kosovo, suggest the need to view women's labor supply decisions at the household rather than individual level. Hence, the need to augment the conventional neo-classical model with a range of household-level variables identifying the demographic, cultural and social drivers of labor market behavior. Given the high overall rate of unemployment in Kosovo, additional variables are included to account for possible added worker and discouraged worker effects. Women's level of social capital, in particular access to information available through the extended internal labor markets, is likely to be an additional factor affecting the probability of participating in the labor market (Calvó-Armengol, 2006; Cappellari \& Tatsiramos, 2015). 
In line with previous studies, the empirical specification allows for a non-linear relationship between age and participation, reflecting the hump-shaped patterns between age and LFP found in other countries. Typically, women's participation falls for those in their 30s, as they temporarily leave the labor market to have children, and peaks amongst those in their 40s when they return (Balleer, GómezSalvador, \& Turunen, 2009). Other demographic variables controlled for in the model include marital status and membership in a minority ethnic group, with Albanian ethnicity defined as the benchmark category. To assess the role of social values, information is extracted from the Millennium Challenge Corporation (MCC) 2017 survey (MCC, 2017). The variable indicates the share of surveyed individuals who agree with the following statement: "it is more important for men in the household to be employed than women". However, this variable is only available at the regional level.

As explained in the previous section, bi-variate analysis suggests that the level of educational attainment is strongly linked to female LFP in Kosovo, in line with the neoclassical model of labor supply whereby educational attainment increases individuals' future earning-power and the opportunity costs of not working. In this investigation, women who have completed less than secondary education as their highest level of education comprise the reference category, whereas two dummy variables are included in the model, indicating attainment of secondary and tertiary education.

Mass temporary and permanent emigration have led to remittances playing a key role in household decision-making in Kosovo. The UNDP's Kosovo Remittance Study found some evidence that FLFP was lower in households receiving remittances (UNDP, 2012). Mendola and Carletto (2009) found that after controlling for potential endogeneity of migration and for the income effect of remittances, having a migrant family member abroad decreased female paid labor supply and reduced unpaid work in Albania. However, women with past family migration experiences were significantly more likely to engage in self-employment and less likely to undertake unpaid work. Shehaj et al. (2016) also controlled 
for the possible endogeneity of receiving remittances and they found a positive effect on FLFP in Albania, but a negative one in North Macedonia. Given that LFS does not include information on remittances, the measure for remittance incidence is extracted from the MCC 2017 survey. The variable measures the share of households in a region receiving remittances in the previous 12 months.

Availability of childcare facilities may be an important factor influencing the decision of a woman to participate. Pre-school education (for 0-5 years), particularly the level 0-3, is the most underdeveloped sector in Kosovo. The gross enrolment rate of children aged 0-5 in pre-schools and pre-primary schools during 2014/2015 was 15.7 percent (MEST, 2016). Having access to kindergartens is expected to positively influence FLFP, though the empirical evidence that public childcare provision raises maternal employment remains weak, partly because of the substitution between informal and formal care (see Asai, Kambayashi, \& Yamaguchi, 2015; Bauernschuster \& Schlotter, 2015; Pronzato \& Sorrenti, 2015; and Christiansen et al., 2016 for recent contributions). To test for this theoretical expectation a variable is included in the regression measuring number of public kindergartens per 1,000 children aged between 1 and 4 years within each municipality (calculation based on data from KAS, 2012a and KAS, 2012b). According to the data from the Ministry of Education, Science and Technology, in 2015/2016, there were only 43 public kindergartens operating in Kosovo, with 11 out of 38 municipalities having no such institutions (MEST, 2016, p. 49). As private childcare provision is not subsidized, and hence is significantly more expensive, public kindergartens provide a better proxy for the availability of affordable childcare.

As mentioned above, the model includes different compositions of households, identified in Table 2. It is expected that having children under five years of age negatively affects FLFP. Although the negative relationship between fertility and female labor force participation has been well established, the two variables may be jointly determined. Women who are less attached to the labor market may decide to have more children than those who are more strongly linked to the 
labor market, implying self-selection into larger families among women with weaker labor market attachment. Using Polish Household Budgets' Survey for 2003-2010, Karbownik and Myck (2016) controlled for endogeneity and found that the OLS estimates overstated the negative effect of childbearing on female labor force participation, but the overall sample of this bias was small. Although the Kosovan LFS contains information on the total number and age of children in the household, it does not allow the identification of their parents, and thus it is not possible to address endogeneity in this analysis.

Identification of whether a household contains any elderly members (aged 65 or older) enables an assessment of the impact of the availability of informal childcare, which may positively affect women's LFP decision. This effect may be particularly important in the context of Kosovo where it is not uncommon for more than two generations of family members to live in the same household (e.g. based on KAS, 2012b data, it is estimated that around one in three households consists of more than one nuclear family). However, the presence of elderly family members may also generate a higher demand for home production and caretaking responsibilities, which in Kosovo are typically borne by women in the household.

The presence of unemployed members in the household is included to test the "added worker effect" hypothesis, i.e. that women enter the labor market to compensate for the unemployment of household members. To the extent that this effect prevails over the "discouraged worker effect" and that labor market conditions are partly controlled by the location dummies in the model, the effect of this variable on female LFP is expected to be positive.

To reflect access to employment opportunities and to infrastructure (including, but not limited to, private childcare provisions, public transportation systems, etc.), the model includes a locational variable and regional employment rate. The regional employment rate is included to depict differing labor market conditions, and given the high inactivity rate, this represents a better measure than the unemployment rate. 
Table 2: Descriptive Statistics

\begin{tabular}{|c|c|c|c|}
\hline Explanatory variables & Women aged 15-64 & Source & $\begin{array}{c}\text { Benchmark } \\
\text { category }\end{array}$ \\
\hline Individual level explanatory variables & & LFS 2013 & \\
\hline Average age & 35.7 years & LFS 2013 & $\mathrm{n} / \mathrm{a}$ \\
\hline Share of married & $62.4 \%$ & LFS 2013 & \multirow{2}{*}{ Single } \\
\hline Share widowed/divorced & $5.1 \%$ & LFS 2013 & \\
\hline Household head & & LFS 2013 & \\
\hline Share non-Albanian & $7.4 \%$ & LFS 2013 & Albanian \\
\hline Share with secondary education & $32.5 \%$ & LFS 2013 & \multirow{2}{*}{$\begin{array}{l}\text { Less than } \\
\text { secondary } \\
\text { education }\end{array}$} \\
\hline Share with tertiary education & $8.2 \%$ & LFS 2013 & \\
\hline \multicolumn{4}{|l|}{ Household level explanatory variables* } \\
\hline $\begin{array}{l}\text { Household type } 2 \text { : a household has children but } \\
\text { no elderly and no unemployed }\end{array}$ & $15 \%$ & LFS 2013 & \multirow{5}{*}{$\begin{array}{c}\text { Households } \\
\text { with no } \\
\text { children, no } \\
\text { unemployed } \\
\text { and no elderly } \\
\text { (Type 1) }\end{array}$} \\
\hline $\begin{array}{l}\text { Household type } 3 \text { : a household that has children } \\
\text { and an unemployed person, but no elderly }\end{array}$ & $8.7 \%$ & LFS 2013 & \\
\hline $\begin{array}{l}\text { Household type } 4 \text { : a household has children, } \\
\text { elderly, and unemployed }\end{array}$ & $5.8 \%$ & LFS 2013 & \\
\hline $\begin{array}{l}\text { Household type 5: a household has no children } \\
\text { but has elderly or unemployed }\end{array}$ & $34.4 \%$ & LFS 2013 & \\
\hline $\begin{array}{l}\text { Household type 6: a household has children under } \\
5 \text { and elderly, but no unemployed }\end{array}$ & $12 \%$ & LFS 2013 & \\
\hline \multicolumn{4}{|l|}{ Socio-economic explanatory variables } \\
\hline $\begin{array}{l}\text { Childcare facilities per } 1,000 \text { children aged } \\
\text { between } 1-4 \text { years }\end{array}$ & $\begin{array}{l}0.5 \text { kindergartens per } \\
1,000 \text { children }\end{array}$ & $\begin{array}{l}\text { KAS and MEST } \\
2015 / 2016\end{array}$ & $\mathrm{n} / \mathrm{a}$ \\
\hline Rural residence (DV) & $58 \%$ & LFS 2013 & $\begin{array}{l}\text { Urban } \\
\text { residence }\end{array}$ \\
\hline $\begin{array}{l}\text { Social values: the average share of individuals } \\
\text { agreeing that "it is more important for men in the } \\
\text { household to be employed than women" }\end{array}$ & $53 \%$ & MCC 2017 & $\mathrm{n} / \mathrm{a}$ \\
\hline Remittance recipients & $20.3 \%$ & MCC 2017 & \\
\hline Ferizaj & $17.8 \%$ & & $\mathrm{n} / \mathrm{a}$ \\
\hline Gjakova & $35.3 \%$ & & $\mathrm{n} / \mathrm{a}$ \\
\hline Gjilan & $20.3 \%$ & & $\mathrm{n} / \mathrm{a}$ \\
\hline Mitrovica & $15.3 \%$ & & $\mathrm{n} / \mathrm{a}$ \\
\hline Peja & $22.2 \%$ & & $\mathrm{n} / \mathrm{a}$ \\
\hline Prishtina & $10.6 \%$ & & $\mathrm{n} / \mathrm{a}$ \\
\hline Prizren & $21.1 \%$ & & $\mathrm{n} / \mathrm{a}$ \\
\hline Regional employment rate & $28.4 \%$ & MCC 2017 & \\
\hline Ferizaj & $33.8 \%$ & & $\mathrm{n} / \mathrm{a}$ \\
\hline Gjakova & $23.4 \%$ & & $\mathrm{n} / \mathrm{a}$ \\
\hline Gjilan & $22.7 \%$ & & $\mathrm{n} / \mathrm{a}$ \\
\hline Mitrovica & $28.0 \%$ & & $\mathrm{n} / \mathrm{a}$ \\
\hline Peja & $23.0 \%$ & & $\mathrm{n} / \mathrm{a}$ \\
\hline Prishtina & $33.3 \%$ & & $\mathrm{n} / \mathrm{a}$ \\
\hline Prizren & $27.4 \%$ & & $\mathrm{n} / \mathrm{a}$ \\
\hline
\end{tabular}

* of working age women

Source: Authors' calculations. 
The average age of working age women in Kosovo is 35.7 years, 62.4 percent of surveyed women are married, 5.1 percent are divorced and remaining 32.5 percent are single. Only 3.4 percent of women are household heads and only 7.4 percent belong to a non-Albanian ethnicity. By education, 32.5 percent of working age women have completed secondary education, only 8.2 percent tertiary education and remaining 59.3 percent have less than secondary education. As explained above, Kosovo operates a small number of public childcare facilities, with only 0.5 kindergartens for 1,000 children aged from 1 to 4 years. There are no available data on capacities/places in these facilities, which would enable a more accurate availability measurement. According to MCC survey, in 2017, on average 53 percent of surveyed individuals considered that "it is more important for men in the household to work than women". By household type, 15 percent of the sampled working age women live in households with children under the age of five, but no elderly and no unemployed; 8.7 percent belong to households with children under the age of five and an unemployed person, but no elderly; 5.8 percent reside in households with children and elderly and unemployed members. The remaining working age women live in households with no children under the age of five, but with either unemployed or an elderly member (34.4 percent), or in households with children under the age of 5 and elderly members, but with no unemployed members (12 percent). According to the MCC commissioned survey (MCC, 2017), in 2017, 20.3 percent of households in Kosovo received remittances, the highest percentage in Gjakova (35.3 percent of households) and the lowest share found in Mitrovica with only 15.3 percent of households receiving remittances. The highest employment rate is recorded in Ferizaj, 33.8 percent, and the lowest in Gjilan at 22.7 percent. 


\section{Empirical Findings}

\subsection{Determinants of Female Labor Force Participation}

This section summarizes the results of the empirical investigation of determinants of FLFP in Kosovo utilizing the probit model specification above and data from the LFS 2013. The sub-sample of interest for this study is working-age women aged 15-64 inclusive, consisting of 27,126 women. Sampling weights are used in the analysis.

The coefficients and marginal effects of the estimated probit model are presented in Table 3. To test the goodness of fit, the McFadden R-square is reported, also known as the "likelihood-ratio index", which compares a model with just the intercept to a model with all parameters (Long \& Freese, 2001). However, Wooldridge states that the goodness of fit is not as important as the statistical and economic significance of the explanatory variables (2010, p. 575).

Following Wooldridge (2010, p. 600), the model is tested for heteroscedasticity. With a Prob $>$ chi $2=0.0000$, we reject the null, suggesting that the model has heteroscedasticity. Therefore, we report marginal effects corrected for heteroscedasticity (using hetprobit command in Stata). With regards to the normality test, Wooldridge (2010) emphasizes that in the response probability, the non-normality in the latent error is a functional form problem, hence it needs to be treated as such and hence there is no need to test or correct for it. Wooldridge further states that inconsistent estimation of coefficients is practically irrelevant: probit might provide very good estimates of the partial effects (Wooldridge, 2010, p. 600).

In line with the findings from other developed and developing countries, a nonlinear relationship is found between age and LFP, women's LFP peaking at the age of 42 , after which the relationship becomes negative. In comparison to single women, married women are less likely to be actively engaged in the labor market (by 4 percentage points), which is likely to be due to the greater role of the latter groups in home production. There is no statistically significant difference between 
the participation of widowed/divorced and single women or between women who are heads of households and those who are not. Compared to Albanian women, women belonging to ethnic minorities in Kosovo have a higher probability of participating in the labor market by 12 percentage points. This is an important finding given concerns about the possible low degree of integration of nonAlbanians into the labor market.

Table 3: LFP Determinants: Probit Marginal Effects, Corrected for Heteroscedasticity

\begin{tabular}{|c|c|c|}
\hline \multirow{2}{*}{ Explanatory variables } & \multicolumn{2}{|c|}{$\mathrm{dy} / \mathrm{dx}$} \\
\hline & Women & Men \\
\hline \multicolumn{3}{|l|}{ Individual level explanatory variables } \\
\hline \multirow[t]{2}{*}{ Age 1} & 0.02 & 0.06 \\
\hline & $(2.01)^{* *}$ & $(8.37)^{* * *}$ \\
\hline \multirow[t]{2}{*}{ Age squared } & -0.0002 & -0.001 \\
\hline & $(-2.05)^{* *}$ & $(-9.15)^{* * *}$ \\
\hline \multirow[t]{2}{*}{ Married (DV) } & -0.04 & 0.15 \\
\hline & $(-2.03)^{* *}$ & $(8.49)^{* * *}$ \\
\hline \multirow[t]{2}{*}{ Widowed/divorced (DV) } & -0.03 & -0.1 \\
\hline & $(-1.43)$ & $(-1.75)^{*}$ \\
\hline \multirow[t]{2}{*}{ Household head } & 0.03 & 0.03 \\
\hline & $(1.29)$ & $(1.39)$ \\
\hline \multirow[t]{2}{*}{ Non-Albanian (DV) } & 0.12 & 0.08 \\
\hline & $(3.52)^{* * *}$ & $(5.92)^{* * *}$ \\
\hline \multirow[t]{2}{*}{ Secondary education $(\mathrm{DV})$} & 0.38 & 0.14 \\
\hline & $(2.25)^{* *}$ & $(12.48)^{* * *}$ \\
\hline \multirow[t]{2}{*}{ Tertiary education (DV) } & 0.93 & 0.28 \\
\hline & $(22.6)^{* * *}$ & $(20.56)^{* * *}$ \\
\hline \multicolumn{3}{|l|}{ Household level explanatory variables } \\
\hline \multirow[t]{2}{*}{ Household type 1 : with children but no elderly and no unemployed } & -0.02 & -0.03 \\
\hline & $(-1.66)^{*}$ & $(-2.63)^{* * *}$ \\
\hline \multirow[t]{2}{*}{ Household type 2: with children and unemployed but no elderly } & 0.09 & 0.21 \\
\hline & $(2.51)^{* *}$ & $(13.59)^{* * *}$ \\
\hline \multirow[t]{2}{*}{ Household type $3:$ with children, elderly, and unemployed } & 0.11 & 0.22 \\
\hline & $(2.79)^{* * *}$ & $(12.66)^{* * *}$ \\
\hline \multirow[t]{2}{*}{ Household type $4:$ with no children but with elderly or unemployed } & 0.1 & 0.17 \\
\hline & $(2.54)^{* *}$ & $(15.14)^{* * *}$ \\
\hline \multirow[t]{2}{*}{ Household type $5:$ with children and elderly but no unemployed } & -0.01 & -0.01 \\
\hline & $(-1.02)$ & $(-0.38)$ \\
\hline \multicolumn{3}{|l|}{ Socio-economic explanatory variables } \\
\hline \multirow[t]{2}{*}{ Childcare services } & 0.02 & 0.03 \\
\hline & $(2.09)^{* *}$ & $(4.38)^{* * *}$ \\
\hline Rural residence (DV) & -0.03 & -0.01 \\
\hline
\end{tabular}




\begin{tabular}{|c|c|c|}
\hline & $(-2.04)^{* *}$ & $(-1.4)$ \\
\hline \multirow[t]{2}{*}{ Remittance recipients } & -0.001 & 0.003 \\
\hline & $(-1.23)$ & $(4.15)^{* * *}$ \\
\hline \multirow[t]{2}{*}{ Social values } & -0 & -0.01 \\
\hline & $(-0.01)$ & $(-5.22)^{* * *}$ \\
\hline \multirow[t]{2}{*}{ Regional employment rate } & 0.002 & 0.01 \\
\hline & $(2.08)^{* *}$ & $(8.12)^{* * *}$ \\
\hline Observations & 27,126 & 27,164 \\
\hline McFadden's R2 & 0.259 & 0.253 \\
\hline Wald test of $\ln s i g m a 2=0$ Prob $>$ chi2: testing for heteroscedasticity & 0 & 0 \\
\hline
\end{tabular}

Notes: ${ }^{*} p<0.1,{ }^{* *} p<0.05,{ }^{* * *} p<0.01$; z-statistics based on robust standard errors in parenthesis; for dummy variables (DV), dy/dx is for the discrete change of DV from 0 to 1.

Source: Authors' calculations.

In line with theoretical expectations, the level of completed education is an important predictor of female LFP. Compared to women with less than secondary education, women who have completed secondary education have a 38 percentage points higher probability of participating in the labor market, whereas having completed higher education is associated with an increase of around 93 percentage points, controlling for other relevant characteristics.

In relation to testing for the fertility, added worker effect and access to informal care or needed additional care for elderly, there are statistically significant differences between defined household types. In comparison to the households with no children, no elderly and no unemployed, living in households with children under the age of five decreases women's participation rate by 2 percentage points, which is in line with theoretical expectations. Compared to the benchmark category, for women living in households with children and unemployed (Type 3 ), the probability of participating in labor force increases by 9 percentage points. This finding is in line with the "added worker effect" and also suggests that an unemployed household member may be able to provide childcare support to the working mother. Further, compared to households with no children, no elderly and no unemployed, living in a household with children under the age of five, but also with unemployed and elderly, the probability of women participating in the labor market increases by 11 percentage points. This finding is in conformity 
with the "added worker" effect and consistent with the hypothesis that other household members are likely to provide informal childcare. The effect of the availability of grandparental childcare has been found to be a statistically and economically significant factor in FLFP in other countries (Pagani \& Marenzi, 2008; Arpino, Pronzato, \& Tavares, 2012; Posadas \& Vidal-Fernandez, 2013). With regards to household Type 5, compared to households with no children, elderly and unemployed, when women reside in households with no children, but with elderly or unemployed, they are more likely to participate in the labor market (higher by 9 percentage points). Again, this indicates support for the "added worker effect". Finally, there is no statistically significant difference in labor force participation between women belonging to households with no children, no elderly, and no unemployed and those living in households with children and elderly, but no unemployed. To sum up, in the absence of informal family care, having children under the age of five reduced female labor force participation, while similar to the findings for other transition economies and Turkey, the "added worker" effect appears to outweigh the "discouraged worker" effect in Kosovo. There is also evidence that informal care provided by elderly household members increases female labor force participation. Access to public childcare in the local municipality is also a significant determinant of FLFP. The availability of an additional public kindergarten per 1,000 children in a municipality is associated with an increase of 2 percentage points in the probability of FLFP. In line with expectations, other factors being equal, women living in rural areas are less likely to participate in the labor market by 3 percentage points. This can be explained by a lack of local employment opportunities, poorer infrastructure which reduces the geographic area of job search, and the more traditional cultural identities and preferences present in rural areas in Kosovo (Siddiqui, Gashi, Higgins, Dasgupta, \& Pucilowski, 2018). Camussi (2013) found that across 57 countries women engaged less in market work where attitudes towards working women were less favorable. Findings suggest that female labor force participation is neither influenced by remittance recipient status nor by social values. However, these two variables are not available at the household level and hence do not 
represent an ideal proxy. Finally, as expected, local labor market conditions are important predictors: women living in regions with a higher employment rate are more likely to participate in the labor market. Other things being equal, a one percentage point increase in the regional employment rate increased a woman's labor force participation by 0.2 percentage points.

\subsection{Explaining the Gender Gap in Participation}

To explore further the gender gap in LFP in Kosovo, the same regression was estimated for males. The comparison of results by gender (Table 3) revealed some interesting differences in the effects of some variables in terms of statistical significance, sign or magnitude.

The age at which LFP peaks for women is 42 , while for men it is 40 . However, the effect of age is stronger in the case of males, i.e. the relationship between the age and LFP is flatter for women. As commonly found in other countries, the impact of marital status differs by gender. Married women are less likely to be economically active than single women, controlling for other characteristics, while married men are more likely to be economically active by around 15 percentage points (compared to single men). Educational attainment (particularly at tertiary level) has a stronger marginal effect on women's LFP.

Rural residence negatively affects the labor force participation of women, but does not seem to influence that of men. While receiving remittances does not impact female labor force participation, it positively influences the male participation rate. This finding may be due to imperfect measure of the remittance incidence variable, but similar evidence has been found in other countries (Posso, 2012). Using data from 66 developing countries from the Middle East and Africa, Asia and the Pacific, Latin America and the Caribbean from 1985 to 2005, Posso (2012) finds a positive and significant relationship between labor supply and remittances. According to Posso (2012), the positive association may be due to non-migrant household members increasing their labor supply to defray 
migration-related expenses and/or that remittances generate employment when money flows into households.

While the variable controlling for social values is insignificant for women, it negatively influences labor force participation of men, i.e. in regions where a higher share of individuals consider that men should be employed before women, participation of men in the labor market is lower. This is an unexpected finding and may be related to the imperfect measure of social values used. Finally, economic conditions measured through regional employment rate have greater positive impact on men than on women ( 1 percentage point and 0.2 percentage points, respectively).

The significance and the sign of variables distinguishing between household types is the same for both genders. However, the magnitude of marginal effects for household types 3, 4, and 5 for men are nearly twice as large as those for women. According to the findings, having children under the age of five and unemployed members increases participation of men more than participation of women. The same applies for households with children and elderly and for those with no children, but with elderly or unemployed. This is in line with the expectation that in a context such as Kosovo, the pressure in securing finances for the family is higher among men, as they are expected and considered to be the key breadwinners in the family. These findings are also consistent with increasing pressure on men to work once they have children and evidence from other European countries shows that men with children are more likely to have higher labor market activity rates compared to other men (Deven, Inglis, Moss, \& Petrie, 1998; Russell, Callahan, \& Keane, 2009). The impact of the other variables on men's LFP is similar to that of women in terms of sign and significance, though their magnitude differs in some cases.

The gender gap in LFP was further analyzed using the Blinder-Oaxaca decomposition technique to discriminate between the part of differences in LFP rates between females and males which can be explained by differences in their 
characteristics (e.g. educational attainment, age, marital status, etc.) and those which can be explained by the difference in the effects on LFP associated with these characteristics (e.g. returns to education). The results of the decomposition using the extension of Blinder-Oaxaca technique for categorical dependent variable models by Bauer and Sinning (2008) and Sinning, Hahn, and Bauer (2008) are presented in Table 4 below. According to these results, the predicted gap in LFP rates of males and females is 37.5 percentage points and statistically significant.

The "explained" part, i.e. part of the LFP differential attributable to observable characteristics that were included in the model (e.g. educational attainment) is positive and significant (Table 4), suggesting that these characteristics contribute towards an increase in the gap in LFP between the two groups, and indicating that males are at a relative advantage with regard to observable characteristics. Namely, higher educational attainment, for instance, among males increases the gap in LFP between the two groups and if females had the same level of educational attainment, the gap in LFP rates would be lower. The "unexplained" part, i.e. of the LFP differential attributable to differences in estimated coefficients is also positive and significant, suggesting that the effect of observable characteristics on the probability to participate in the labor market is also different among men and women, and these also tend to increase the gender gap.

Table 4: Blinder-Oaxaca Decomposition of the Gender Gap in LFP Rates

\begin{tabular}{|c|c|c|c|}
\hline & Share (points) & $P>|t|$ & Share (\%) \\
\hline Characteristics effect & 0.039 & 0.00 & 10 \\
\hline Coefficients effect & 0.353 & 0.00 & 90 \\
\hline Raw difference & 0.392 & 0.00 & 100 \\
\hline
\end{tabular}

Notes: ${ }^{*} \mathrm{p}<0.1,{ }^{* *} \mathrm{p}<0.05,{ }^{* * *} \mathrm{p}<0.01 ; \mathrm{z}$-statistics based on robust standard errors in parenthesis; for dummy variables (DV), dy/dx is for the discrete change of DV from 0 to 1.

Source: Authors' calculations. 
Under the assumption that the LFP structure of males would prevail in the absence of an "unexplained difference", only 3.9 percentage points (or 10 percent) of the raw LFP gap of 39.1 percentage points would be explained by observable characteristics such as education, etc. While part of this 90 percent "unexplained" difference could be explained by unobserved differences between men and women that are not included in the empirical model, the results are consistent with a significant presence of gender discrimination in the Kosovan labor market.

\section{Results and Discussions}

The above analyses of labor force participation suggest that both supply and demand side factors are important in explaining the low FLFP and large gender gap in participation in Kosovo. This is consistent with the findings of previous recent studies of low female participation in labor markets. The obtained evidence is also consistent with a significant presence of gender discrimination in the Kosovan labor market.

The results confirm the commonly found effects of age, marital status, and education on FLFP and provide new evidence on the importance of household composition and labor demand conditions. The findings support the decision taken to adopt a household level analysis of participation. The finding that nonAlbanian ethnic women are more likely, other things being equal, to participate in the labor market than Albanian women is particularly interesting given the continuing problems in integrating different ethnic communities in Kosovo.

Given the findings of previous related research, the results above indicating the importance of provision of local public childcare in Kosovo is especially important. Given the high incidence in Kosovo of households containing at least three generations of the same extended family, the finding that the provision of a local public childcare facility had a significant positive effect on FLFP will be of interest to policymakers. As Kinoshita and Guo (2015) point out, a high FLFP is frequently associated with ample and flexible childcare provision designed 
to meet the differing demands of parents. In Kosovo, the prevalence of schools operating a two or three shift system further complicates attempts to reconcile the roles of a parent and an employee. Eliminating the shift system would likely have a similar positive effect on FLFP as extending the length of a school day had in other countries (Contreras \& Sepulveda, 2016).

Also of interest to policymakers will be the strong effect of higher educational attainment on the probability of a woman being both a participant in the labor market and in employment. While employed women are, on average, more educated than employed men in Kosovo, women of working age have lower average educational attainment than men. In 201360 percent of women aged between 15 and 64 had less than secondary education compared to just 33 percent of men (KAS, 2014). Reducing this latter proportion would be likely to raise FLFP and indeed this gender education gap has now been closed among the younger age groups (KAS, 2015).

Finally, while the sectoral composition of the economy may not currently be a significant cause of the gender differences in overall labor market outcomes, the under-representation of women in the major employment-providing private sector industries warrants the attention of researchers and policymakers, particularly since it is likely to become a more important factor over time as the relative importance of the private sector in job creation increases. 


\section{Literature}

Akerlof, G., \& Kranton, R. (2000). Economics and identity. The Quarterly Journal of Economics, 115(3), 715-753. doi: https://doi.org/10.1162/003355300554881

Arpino, B., Pronzato, C., \& Tavares, L. (2012). Mothers' labour market participation: Do grandparents make it easier? IZA Working Paper No. 7065. Retrieved from: http://ftp.iza.org/dp7065.pdf

Asai, Y., Kambayashi, R., \& Yamaguchi, S. (2015). Childcare availability, household structure and maternal employment. Journal of Japanese and International Economics, 38, 172-192. doi: https://doi.org/10.1016/j.jjie.2015.05.009

Assaad, R., Hendy, R., Lassassi, M., \& Yassin, S. (2018). Explaining the MENA paradox: Rising educational attainment, yet stagnant female labour force participation. IZA Discussion Paper No. 11385. Retrieved from: https://www.iza. org/de/publications/dp/11385/explaining-the-mena-paradox-rising-educationalattainment-yet-stagnant-female-labor-force-participation

Balleer, A., Gómez-Salvador, R., \& Turunen, J. (2009). Labour force participation in the Euro Area - a cohort-based analysis. European Central Bank Working Paper No. 1049. Retrieved from: https://www.ecb.europa.eu/pub/pdf/scpwps/ ecbwp1049.pdf?ab798db3ab622da41537b986f4038349b

Bandiera, O., \& Natraj, A. (2013). Does gender inequality hinder development and economic growth? Evidence and policy implications. The World Bank Research Observer, 28(1), 2-21. doi: https://doi.org/10.1093/wbro/lks012

Bauer, T., \& Sinning, M. (2008). An extension of the Blidner-Oaxaca decomposition to nonlinear models. Advances in Statistical Analysis, 92(2), 197-206. doi: https://doi.org/10.1007/s10182-008-0056-3

Bauernschuster, S., \& Schlotter, M. (2015). Public child care and mother's labour supply - Evidence from two quasi-experiments. Journal of Public Economics, 123, 1-16. doi: https://doi.org/10.1016/j.jpubeco.2014.12.013 
Bayanpourtehrani, G., \& Sylwester, K. (2013). Female labour force participation and religion: Cross country analysis. Bulletin of Economic Research, 65(2), 107-33. doi: https://doi.org/10.1111/j.1467-8586.2012.00443.x

Berger, E. (2013). Happy working mothers? Investigating the effect of maternal employment on life satisfaction. Economica, 80(317), 23-43. doi: https://doi. org/10.1111/j.1468-0335.2012.00932.x

Bertrand, M. (2011). New perspectives on gender. In O. Ashenfelter and D. Card (Eds.), Handbook of labor economics (Vol. 4B, pp. 1545-92). Amsterdam: Elsevier.

Bick, A., \& Fuchs-Schündeln, N. (2012). Taxation and labour supply of married women across countries. CEPR Discussion Paper No. 9115. Retrieved from: http:// www.cepr.org/active/publications/discussion_papers/dp.php?dpno=9115

Blau, F., \& Kahn, L. (2013). Female labour supply: Why is the United States falling behind? American Economic Review, 103(3), 251-256. doi: http://dx.doi. Org/10.1257/aer.103.3.251

Calvó-Armengol, A. (2006). Social networks and labour market outcomes. Els Opuscles del CREI, 17, 1-25. Retrieved from: http://www.crei.cat/wp-content/ uploads/opuscles/090429175233_ENG_op17ang.pdf

Camussi, S. (2013). Female labour market participation and cultural values. Bank of Italy Occasional Paper No. 178. Retrieved from: https://papers.ssrn.com/sol3/ papers.cfm?abstract_id=2297874

Cappellari, L., \& Tatsiramos, K. (2015). With a little help from my friends? Quality of social networks, job finding and job match quality. European Economic Review, 78, 55-75. doi: https://doi.org/10.1016/j.euroecorev.2015.04.002

Christiansen, L., Lin, H., Pereira, J., Topalova, P., \& Turk, R. (2016). Individual choice or policies? Drivers of female employment in Europe. IMF Working Paper No. WP/16/49. Retrieved from: https://www.imf.org/en/Publications/ WP/Issues/2016/12/31/Individual-Choice-or-Policies-Drivers-of-FemaleEmployment-in-Europe-43770 
Cipollone, A., Patacchini, E., \& Vallanti, G. (2014). Female labour market participation in Europe: Novel evidence on trends and shaping factors. IZA Journal of European Labour Studies, 3, 1-40. doi: https://doi.org/10.1186/21939012-3-18

Contreras, D., \& Sepulveda, P. (2016). Effect of lengthening the school day on mother's labour supply. World Bank Economic Review, 31(3), 747-766. doi: https://doi.org/10.1093/wber/lhw003

Curberes, D., \& Teignier, M. (2015). How costly are labor gender gaps? Estimates for the Balkans and Turkey. World Bank Policy Review Working Paper No. 7319. Retrieved from: http://documents.worldbank.org/curated/ en/999501467991022574/How-costly-are-labor-gender-gaps-estimates-for-theBalkans-and-Turkey

Deven, F., Inglis, S., Moss, P., \& Petrie, P. (1998). State of the art review on the reconciliation of work and family life for men and women and the quality of care services. DfEE Research Brief No. 44. Retrieved from: http://webarchive. nationalarchives.gov.uk/20130402105226/https://www.education.gov.uk/ publications/eOrderingDownload/RB44.pdf

Duflo, E. (2012). Women's empowerment and economic development. Journal of Economic Literature, 50(4), 1051-79. doi:10.3386/w17702

Eckstein, Z., \& Lifshitz, O. (2015). Household interaction and the labor supply of married women. International Economic Review, 56(2), 427-55. doi: https:// doi.org/10.1111/iere.12110

Eurostat. (2019). Employment and unemployment (LFS). Retrieved from: https:// ec.europa.eu/eurostat/web/lfs/data/database

Fernández, R. (2013). Culture changes as learning: The evolution of female labour force participation over a century. American Economic Review, 103(1), 472-500. doi: https://doi.org/10.1257/aer.103.1.472 
Fernández, R., Fogli, A., \& Olivetti, C. (2004). Mothers and sons: Preference formation and female labour force dynamics. Quarterly Journal of Economics, 119(4), 1249-1299. doi: https://doi.org/10.1162/0033553042476224

García-Pereiro, T., \& Dileo, I. (2017). Tracking the factors that influence female employment: The Albanian case. Rivista Italiana di Economia Demografia e Statistica, 71(3), 77-88. Retrieved from: http://www.sieds.it/listing/RePEc/ journl/2017LXXI_N3_RIEDS_25_Garcia-Pereiro_Dileo.pdf

Goldin, C. (2006). The quiet revolution that transformed women's employment, education and family. American Economic Review, 96(2), 1-21. doi: https://doi. org/10.1257/000282806777212350

Goldin, C. (2014). Agrand gender convergence: Its last chapter. American Economic Review, 104(4), 1091-1119. doi: http://dx.doi.org/10.1257/aer.104.4.1091

Gouda, M., \& Potrafke, N. (2016). Gender equality in muslim-majority countries. Economic Systems, 40(4), 683-98. doi: https://doi.org/10.1016/j. ecosys.2016.04.002

International Monetary Fund (IMF). (2013). Women, work and the economy: Macroeconomic gains from gender equality. IMF Discussion Note No. 13/10. Retrieved from: http://www.imf.org/external/pubs/ft/sdn/2013/sdn1310.pdf

Kabeer, N. (2012). Women's economic empowerment and inclusive growth: Labour markets and enterprise development. CDPR Discussion Paper No. 29/12. Retrieved from: https://www.soas.ac.uk/cdpr/publications/papers/file80432.pdf

Karaoglan, D., \& Okten, C. (2012). Labour force participation of married women in Turkey: Is there an added or discouraged worker effect? IZA Discussion Paper No. 6616. Retrieved from: http://ftp.iza.org/dp6616.pdf

Karbownik, K., \& Myck, M. (2016). For some mothers more than others? How children matter for labour market outcomes when both fertility and female employment are low. Economics of Transition and Institutional Change, 24(4), 705-25. doi: https://doi.org/10.1111/ecot.12104 
Khitarishvili, T. (2013). The economic crisis of 2008 and the added worker effect in transition countries. Working Paper No. 765. Retrieved from: http://www. levyinstitute.org/pubs/wp_765.pdf

Kinoshita, Y., \& Guo, F. (2015). What can boost female labour force participation in Asia? IMF Working Paper No. 15/56. Retrieved from: https://www.imf.org/ external/pubs/ft/wp/2015/wp1556.pdf

Klasen, S., \& Pieters, J. (2015). What explains the stagnation of female labour force participation in urban India? World Bank Economic Review, 29(3), 449-478. doi: https://doi.org/10.1093/wber/lhv003

Kosovo Agency of Statistics (KAS). (2012a). Education statistics 20112012. Retrieved from: http://ask.rks-gov.net/media/1645/sattistikat-earsimit-2011-2012.pdf

Kosovo Agency of Statistics (KAS). (2012b). Kosovo Population and Housing Census 2011 final results: Main data. Prishtina: KAS. Retrieved from: http://ask. rks-gov.net/media/2074/te-dhenat-kryesore.pdf

Kosovo Agency of Statistics (KAS). (2014). Results of the Kosovo 2013 Labour Force Survey. Retrieved from: http://ask.rks-gov.net/sq/agjencia-e-statistikave-tekosoves/add-news/rezultatet-e-anketes-se-fuqise-punetore-2013-ne-kosove

Kosovo Agency of Statistics (KAS). (2015). Women and men in Kosovo. Retrieved from: http://ask.rks-gov.net/media/1707/grate-dhe-burrat-ne-kosove-2014.pdf

Kosovo Agency of Statistics (KAS). (2018). Results of the Kosovo 2017 Labour Force Survey. Retrieved from: http://ask.rks-gov.net/sq/agjencia-e-statistikave-tekosoves/add-news/anketa-e-fuqise-punetore-afp-2017

Long, J.S., \& Freese, J. (2001). Regression models for categorical dependent variables using Stata. College Station,TX: Stata Press.

Millennium Challenge Corporation (MCC). (2017). Kosovo - Labor Force \& Time Use Survey. Retrieved from: https://data.mcc.gov/evaluations/index.php/ catalog/205/get_microdata 
Ministry of Education, Science and Technology (MEST). (2016). Education statistics in Kosovo. Retrieved from: http://masht-smia.net/Publikimet/0aALB.pdf

Mendola, M., \& Carletto, G. (2009). International migration and gender differentials in the home market: Evidence from Albania. World Bank Policy Research Working Paper No. 4900. Retrieved from: http://documents.worldbank. org/curated/en/892271468006291314/International-migration-and-genderdifferentials-in-the-home-labor-market-evidence-from-Albania

Nejad, M., \& Young, A. (2014). Female brain drains and women's rights gap: A gravity model analysis of bi-lateral flows. IZA Discussion Paper No. 8067. Retrieved from: http://anon-ftp.iza.org/dp8067.pdf

Oaxaca, R., \& Ransom, M. (1994). On discrimination and the decomposition of wage differentials. Journal of Econometrics, 61(1), 5-21. doi: https://doi. org/10.1016/0304-4076(94)90074-4

Olivetti, C., \& Petrongolo, B. (2016). The evolution of the gender gap in industrialised countries. CEPR Discussion Paper No. 11034.

Pagani, L., \& Marenzi, A. (2008). The labor market participation of sandwich generation Italian women. Journal of Family and Economic Issues, 29(3), 427-44. doi: https://doi.org/10.1007/s10834-008-9112-0

Pastore, F., Sattar, S., \& Tiongson, E. (2013). Gender differences in earnings and labour supply in early career: Evidence from Kosovo's school-to-work transition survey. IZA Discussion Paper No. 7461. Retrieved from: http://ftp.iza.org/dp7461. pdf

Posadas, J., \& Vidal-Fernandez, M. (2013). Grandparents' childcare and female labor force participation. IZA Journal of Labor Policy, 2(14), 1-20. doi: https:// doi.org/10.1186/2193-9004-2-14

Posso, A. (2012). Remittances and aggregate labor supply: Evidence from sixty-six developing nations. The Developing Economies Journal, 50(1), 25-39. doi: https:// doi.org/10.1111/j.1746-1049.2011.00153.x 
Pronzato, C., \& Sorrenti, G. (2015). When context does matter. Childcare and maternal employment: Trying to solve the puzzle. CESifo DICE Report, 13(1), 3-8. Retrieved from: https://www.ifo.de/DocDL/dicereport115-forum1.pdf

Russell, H., Callahan, T., \& Keane, C. (2009). A woman's place: Female participation in the Irish labour market. ESRI Equality Research Series. Retrieved from: https://www.esri.ie/publications/a-womans-place-female-participation-inthe-irish-labour-market/

Shehaj, E., Bimbashi, E., Rizvanolli, A., Gashi, A., Elshani, D., Abazi-Alili, H., Atanasovska, V., Angelelovska, T., Marcic, M., Kovacic, N., \& Adnett, N. (2016). Women's inclusion in socio-economic life: Determinants of female labour force participation in the Western Balkans. Tirana: Faculty of Economics, University of Tirana. Retrieved from: http://staging.bitsia.com/aer/wp-content/ uploads/2017/12/Determinants-of-Female-Labour-Force-Participation-in-theWestern-Balkans.pdf

Siddiqui, H., Gashi, A., Higgins, J., Dasgupta, B., \& Pucilowski, M. (2018). MCC Kosovo labor force and time use study research report. Arlington, VA: Social Impact Inc. Retrieved from: https://millenniumkosovo.org/wp-content/ uploads/2018/11/MCC-Kosovo-Labor-Force-and-Time-Use-Study-FinalResearch-Report-1.pdf

Sinning, M., Hahn, M., \& Bauer, T. (2008). The Blinder-Oaxaca decomposition for nonlinear regression models. The Stata Journal, 8(4), 480-492. doi: https:// doi.org/10.1177/1536867X0800800402

Spierings, N., Smits, J., \& Verloo, M. (2009). On the compatibility of Islam and gender equality: Effects of modernisation, state Islamization and democracy of women's labour market participation in 45 Muslim countries. Social Indicators Research, 90(3), 503-22. doi: https://doi.org/10.1007/s11205-008-9274-z

Stotsky, J., Shibuya, S., Kolovich, L., \& Kebhaj, S. (2016). Trends in gender equality and women's advancement. IMF Working Paper No. 16/21. Retrieved from: https://www.imf.org/external/pubs/ft/wp/2016/wp1621.pdf 
United Nations Development Programme (UNDP). 2012. Kosovo Remittance Study. Prishtina: UNDP. Retrieved from: https://www.undp.org/content/dam/ kosovo/docs/Remitances/KRS2012_English_858929.pdf

Uraz, A., Aran, M., Hüsamoğlu, M., Okkali Sanalmis, D., \& Capar, S. (2010). Recent trends in female labour force participation in Turkey. State Planning Organisation of the Republic of Turkey and World Bank Welfare and Social Policy Analytical Work Program Working Paper No. 2. Retrieved from: http://siteresources. worldbank.org/INTTURKEY/147254-1268836253913/22537996/ RecentTrendsInFemaleLaborForceParticipationInTurkey.pdf

Verne, P., Barry, A., \& Guennouni, J. (2014). Female labour participation in the Arab World: Some evidence from panel data in Morocco. World Bank Policy Research Paper No. 7031. Retrieved from: http://documents.worldbank.org/ curated/en/909281468060906502/Female-labor-participation-in-the-Arabworld-some-evidence-from-panel-data-in-Morocco

Wooldridge, J. (2010). Econometric analysis of cross section and panel data. Cambridge, MA: MIT Press.

World Bank. (2014). Kosovo: A note on recent labor market developments. Unpublished manuscript, Washington, DC: World Bank.

World Bank. (2018). World Development Indicators database. Retrieved from: https://data.worldbank.org/ 